\title{
PEMETAAN FAKTOR KUNCI PENGEMBANGAN EKONOMI PERIKANAN: STUDI KOMPARATIF PADA TIGA KABUPATEN DI PROVINSI RIAU
}

\section{Mapping of Key Factors for Fisheries Economic Development: A Comparative Study in Three District in Riau Province}

\author{
*Tomi Ramadona ${ }^{1}$, Pareng Rengi ${ }^{1}$, dan Fanny Septya ${ }^{2}$ \\ ${ }^{1}$ Fakultas Perikanan dan Kelautan, Universitas Riau, \\ Kampus Bina Widya Km 12,5 Simpang Baru, Pekanbaru; Indonesia \\ ${ }^{2}$ Fakultas Pertanian, Universitas Riau, \\ Kampus Bina Widya Km 12,5 Simpang Baru, Pekanbaru; Indonesia \\ Diterima tanggal: 17 Agustus 2018 Diterima setelah perbaikan: 28 Juni 2019 \\ Disetujui terbit: 10 Desember 2019
}

\begin{abstract}
ABSTRAK
Provinsi Riau memiliki potensi perikanan berupa perikanan tangkap dan budi daya yang tersebar pada seluruh kabupaten. Sehingga, diperlukan perencanaan dengan mempertimbangkan faktor kunci pengembangan ekonomi perikanan berbasis wilayah. Penelitian ini bertujuan untuk memetakan faktor kunci Pengembangan Ekonomi Perikanan PEP pada tiga (3) kabupaten di Provinsi Riau yaitu Kabupaten Indragiri Hilir, Kabupaten Bengkalis dan Kabupaten Kampar. Penelitian ini menggunakan metode survei. Data yang dikumpulkan terdiri dari data primer dan sekunder yang diperoleh baik secara langsung di lapangan maupun studi literatur. Penentuan responden dilakukan secara purposive terhadap tokoh kunci setiap daerah. Analisis data yang digunakan yaitu analisis Multi Dimensional Scaling (MDS) dengan teknik Rafed dan analisis kebijakan dengan teknik prospektif dan gabungan. Hasil analisis menunjukkan karakteristik lokasi, potensi sumber daya dan kultur masyarakat menyebabkan faktor kunci pengembangan ekonomi perikanan pada masing-masing daerah secara umum relatif berbeda. Faktor kunci PEP Kabupaten Indragiri Hilir yaitu: (1) kebijakan pengembangan komunitas; (2) kerjasama dalam industri sejenis maupun industri hulu-hilir; (3) kontribusi pengembangan ekonomi perikanan terhadap peningkatan kualitas hidup dan kesejahteraan masyarakat lokal; (4) faktor kebijakan pemerintah; (5) Ketersediaan sumber daya manusia (SDM), dan; (6) sarana dan prasarana perikanan. Faktor kunci PEP Kabupaten Bengkalis yaitu: (1) peluang kerjasama dalam industri sejenis maupun industri hulu-hilir; (2) kontribusi pengembangan ekonomi perikanan terhadap peningkatan kualitas hidup dan kesejahteraan masyarakat lokal; (3) sinkronisasi lintas sektoral dan spasial dalam perencanaan PEP; (4) faktor kebijakan pemerintah, dan; (5) ketersediaan SDM. Faktor kunci PEP Kabupaten Kampar yaitu: (1) pusat layanan investasi; (2) jumlah lembaga keuangan lokal; (3) status asosiasi industri komoditi/ forum bisnis; (4) ketersediaan SDM, dan; (5) sarana dan prasarana perikanan. Dalam rangka optimalisasi kontribusi sektor perikanan maka diperlukan kebijakan penguatan seluruh faktor kunci PEP pada masing-masing daerah melalui implementasi program pada Satuan Kerja Perangkat Daerah (SKPD) terkait.
\end{abstract}

Kata kunci: penelitian komparasi; ekonomi perikanan; faktor kunci; MDS; survei

\begin{abstract}
Riau Province has potential capture fisheries and aquaculture spread throughout the district. So it is necessary to plan the development of regional fisheries economic. This research aims to map the key factors of Fisheries Economic Development (FED) in 3 district of Riau Province, they are Indragiri Hilir, Bengkalis and Kampar. This research used a survey method. It collected primary and secondary data through interviews and literature studies. The respondents were purposive sampling of key persons in each region. Data were analyzed using Multi Dimensional Scaling (MDS) analysis by Rafed technique, while prospective and combine techniques were used to policy analysis. The analysis resulting in the differentiation of the key factors to the economic fisheries which are specific to location, potential resources, and social culture. The key factors of FED in Indragiri Hilir District are: (1) community development policies; (2) cooperation among similar industries and upstream-downstream industries; (3) contribution of fisheries economic development to the improvement of life quality and welfare of the local communities; (4) government policy; 5) Availability of HR, and; (6) fisheries facilities and infrastructure. The key factor of FED in Bengkalis District are: (1) cooperation opportunity among similar industries and upstream-downstream industries; (2) contribution of fisheries economic
\end{abstract}


development to the improvement of life quality and welfare of the local communities; (3) cross-sectoral and spatial synchronization in FED planning; (4) government policy, and; (5)availability of HR. The key factor of FED in Kampar District is: (1) investment service center;(2) number of local financial institutions; (3) status of the commodity industry association / business forum; (4) availability of $H R$, and; (5) fisheries facilities and infrastructures. It is necessary to reinforce all the key factors of FED in each districts by implementing relevant local government programs in order to optimize the contribution of fisheries sector.

Keywords: comparative research; fisheries economy; key factors; MDS; survey

\section{PENDAHULUAN}

Optimalisasi pembangunan daerah haruslah berlandaskan pada kondisi, potensi serta keinginan masyarakat, sehingga karakteristik yang dimiliki oleh masing-masing daerah menjadi pertimbangan penting dalam perencanaan pembangunan. Perencanaan ini nantinya akan memberikan arahan dalam pengelolaan sumber daya setiap daerah. Demikian juga halnya dengan sektor perikanan, pengelolaan dan pengembangan berbasis karakter wilayah menjadi suatu panduan dalam rangka meningkatkan kesejahteraan masyarakat.

Pengembangan Ekonomi Perikanan (PEP) merupakan pengejawantahan dari Pengembangan Ekonomi Lokal (PEL) yang digagas oleh Bappenas. PEL pada tingkat nasional merupakan urgensi dan kebutuhan mendasar yang sangat diperlukan baik oleh daerah yang masuk dalam kategori maju maupun daerah yang masih relatif tertinggal. Oleh karena itu, diperlukan strategi dan upaya pemanfaatan sumber daya dan sumber dana untuk menggerakkan ekonomi lokal dengan meningkatkan peran seluruh stakeholder terkait melalui kerangka regulasi, kerangka investasi, dan layanan publik secara utuh dan saling terkait satu sama lain (Bappenas, 2007).

Provinsi Riau memiliki karakteristik khas di bidang perikanan dengan segenap potensi dan permasalahannya. Dari segi produksi, usaha perikanan di Provinsi Riau berasal dari darat dan laut. Daerah sebagai penghasil ikan terbanyak pada tahun 2016 adalah Kabupaten Rokan Hilir $68.160,2$ ton (31,07 persen), Kabupaten Kampar $59.550,9$ ton $(27,14$ persen), dan Kabupaten Indragiri Hilir $44.128,8$ ton (20,11 persen). Sisanya sebanyak $47.566,3$ ton $(21,17$ persen) tersebar di kabupaten/ kota lainnya (BPS Provinsi Riau, 2017). Dari segi posisi, Provinsi Riau diuntungkan oleh letak yang strategis yaitu berada dekat jalur perdagangan internasional (Indonesia-Singapura, Malaysia dan Thailand). Dari segi sosial-budaya, masyarakat Melayu Riau sudah dikenal memiliki sejarah yang kuat dalam budaya bahari.

Berdasarkan uraian di atas, perencanaan wilayah sangat penting untuk pembangunan sektor perikanan di Provinsi Riau. Hal ini karena setiap wilayah memiliki karakteristik yang berbeda sehingga kebutuhan fasilitasnya pun berbeda. Perencanaan wilayah dengan mengedepankan pengembangan ekonomi perikanan diperlukan untuk mencapai program pembangunan menjadi tepat sasaran. Provinsi Riau memiliki potensi perikanan yang besar, lokasi yang strategis dan budaya bahari yang kuat, oleh karena itu diperlukan perencanaan dengan mempertimbangkan faktor kunci pengembangan ekonomi perikanan berbasis wilayah. Tujuan penelitian ini untuk memetakan faktor kunci PEP pada 3 kabupaten yang mewakili karakteristik wilayah di Provinsi Riau.

\section{METODOLOGI}

\section{Lokasi dan Waktu Penelitian}

Lokasi kajian berada di tiga (3) kabupaten di Provinsi Riau meliputi Kabupaten Indragiri Hilir, Kabupaten Bengkalis, dan Kabupaten Kampar. Alasan pemilihan lokasi kajian yaitu daerahdaerah objek penelitian dapat mewakili daerah perikanan di Provinsi Riau. Kabupaten Indragiri Hilir mewakili Kabupaten Pelalawan dan Kabupaten Siak dengan perairan pantai menghadap Laut China Selatan serta potensi perikanan berupa perikanan laut dan perairan umum. Kabupaten Bengkalis mewakili Kota Dumai, Kabupaten Rokan Hilir dan Kabupaten Kepulauan Meranti dengan perairan pantai menghadap Selat Malaka serta potensi berupa perikanan tangkap. Kabupaten Kampar mewakili perikanan darat sebagai daerah penghasil budi daya air tawar seperti Kuansing, Pekanbaru, Rokan Hulu dan Indragiri Hulu. Penelitian ini dilaksanakan pada Bulan Juni - November Tahun 2014 dan Juni - Agustus Tahun 2018. 


\section{Jenis dan Metode Pengambilan Data}

Indikator/ atribut yang digunakan dalam penelitian ini mengacu pada indikator Pengembangan Ekonomi Lokal (PEL) Bappenas Tahun 2007 dengan beberapa penyesuaian berdasarkan diskusi pakar. Data primer diperoleh dari hasil survey lapangan melalui responden kunci, sedangkan data sekunder diperoleh dari publikasi dan literatur karya ilmiah serta instansi terkait. Teknik pengambilan sampel dilakukan dengan cara purposive sampling sesuai dengan kelompok sasaran kajian, dengan pertimbangan sebagai berikut: (1) keterkaitan dengan tujuan pelaksanaan studi; (2) representasi dari populasi, dan; (3) ketepatan dalam menjawab setiap pertanyaan. Responden kunci berasal dari berbagai instansi dengan jumlah disesuaikan karakteristik masingmasing wilayah dengan pertimbangan jumlah SKPD terkait, jumlah pelaku usaha, jumlah akademisi/peneliti dan pengaruh stakeholder lainnya.

\section{Metode Analisis}

Analisis data dalam kajian ini menggunakan analisis keberlanjutan MDS dengan teknik Rafed (Rapid Assessment Techniques for Fisheries Economic Development) yang merupakan modifikasi dari Rapfish yang dikembangkan oleh Fisheries Center, University of British Columbia (Kavanagh, 2001; Pitcher, 1999;). Metode MDS merupakan teknik analisis statistik berbasis komputer dengan menggunakan software Rapfish untuk seluruh aspek secara komprehensif. Analisis ini dilakukan melalui tahapan MDS untuk melihat faktor kunci pengembangan ekonomi perikanan. Jenis-jenis aspek dan atribut/faktor dalam kajian ini ditentukan dengan mengacu pada indikator FAO (FAO, 2007) dan PEL (Bappenas, 2007) serta kondisi karakteristik wilayah berdasarkan pendapat pakar.

Dalam rangka menentukan faktor kunci pengembangan ekonomi perikanan, maka dilakukan analisis kebijakan dengan menggunakan analisis prospektif dan analisis kebutuhan. Kegunaan analisis prospektif yaitu untuk mempersiapkan tindakan strategis yang perlu dilakukan dan melihat perubahan yang dibutuhkan di masa depan (Bourgoise dalam Ramadona, Rengi \& Marnis, 2015). Prosedur analisis dilakukan sebagai berikut; Tahapan awal, ditentukan faktor-faktor pengungkit melalui teknik MDS (Triyono dan Ramadona, 2018), kemudian dilakukan analisis matrik pengaruh dan ketergantungan untuk melihat posisi setiap faktor dalam pengembangan ekonomi perikanan dengan menggunakan software analisis prospektif, faktorfaktor kunci juga diidentifikasi melalui analisis kebutuhan. Selanjutnya, hasil analisis kebutuhan dideskripsikan dalam matriks dan digabungkan dengan hasil analisis MDS (Rengi, 2015)

\section{HASIL DAN PEMBAHASAN}

\section{Faktor Kunci Pengembangan Ekonomi Perikanan Kabupaten Indragiri Hilir}

Kabupaten Indragiri Hilir dengan ibukota Tembilahan merupakan salah satu Kabupaten pesisir di Provinsi Riau dengan potensi utama dibidang perikanan tangkap. Usaha perikanan di daerah ini masih perlu dibenahi (Rosyidah dan Erlina, 2018). Selain itu daerah ini juga memiliki

Tabel 1. Jumlah dan Distribusi Responden.

Table 1. Number and Distribution of Respondents.

\begin{tabular}{clc} 
Kabupaten/ Regency & \multicolumn{1}{c}{$\begin{array}{c}\text { Asal stakeholder/ } \\
\text { Origin of stakeholders }\end{array}$} & $\begin{array}{c}\text { Jumlah Responden/ } \\
\text { Number of Respondents }\end{array}$ \\
\hline Indragiri Hilir & Pemerintah Daerah/ Local government & 4 \\
& Pelaku Usaha (Praktisi)/ Businessmen & 2 \\
& Akademisi, Peneliti/ Academics, Researcher & 3 \\
Bengkalis & Stakeholder Lainnya/ Other Stakeholders & 1 \\
& Pemerintah Daerah / Local government & 2 \\
& Pelaku Usaha (Praktisi)/ Businessmen & 1 \\
Kampar & Akademisi, Peneliti/ Academics, Researcher & 3 \\
& Stakeholder Lainnya/ Other Stakeholders & 1 \\
& Pemerintah Daerah / Local government & 2 \\
& Pelaku Usaha (Praktisi)/ Businessmen & 2 \\
& Akademisi, Peneliti/ Academics, Researcher & 2 \\
& Stakeholder Lainnya/ Other Stakeholders & 2 \\
\hline
\end{tabular}


potensi budi daya air payau (tambak), budi daya laut (KJA), budi daya air tawar dan usaha pengolahan produk perikanan. Hasil analisis MDS menunjukkan bahwa dari 77 atribut yang dianalisis, diperoleh 11 atribut yang sensitif berpengaruh terhadap keberlanjutan pengembangan ekonomi perikanan di Kabupaten Indragiri Hilir yaitu; promosi produk perikanan dari pemerintah daerah (A6); upaya fasilitas pemodalan dari pemerintah (A7); peluang kerjasama dalam industri sejenis maupun industri hulu-hilir (B8); akses ke pelabuhan udara (B15); kebijakan pengembangan komunitas (C4); kebijakan kerjasama antar daerah/ pemda (C3); kebijakan persaingan usaha (C14); kKontribusi pengembangan ekonomi perikanan terhadap peningkatan kualitas hidup dan kesejahteraan masyarakat lokal (D5); restrukturisasi organisasi pemerintah (E5); sinkronisasi lintas sektoral dan spasial dalam perencanaan PEP (F7); frekuensi dilakukan evaluasi mandiri (F3). Hasil analisis faktor/atribut pengungkit (leverage attributes) ditampilkan pada Gambar 1.

Gambar 1 menampilkan faktor sensitif yang memiliki pengaruh terhadap PEP Kabupaten Indragiri Hilir. Nilai atribut yang lebih tinggi mengindikasikan kepentingan pemangku kepentingan atas atribut yang sesuai dalam pengelolaan perikanan (Adiga,. Ananthan, Ramasubramanian, Kumari, 2016). Sebelas (11) faktor sensitif tersebut selanjutnya dianalisis tingkat kepentingan antar faktor terhadap kinerja pengembangan ekonomi perikanan dengan menggunakan analisis prospektif. Output dari hasil analisis prospektif berupa ranking dan sektor dari masing-masing atribut yang digambarkan dalam diagram empat sektor/kuadran beserta koordinatnya disajikan pada Gambar 2.

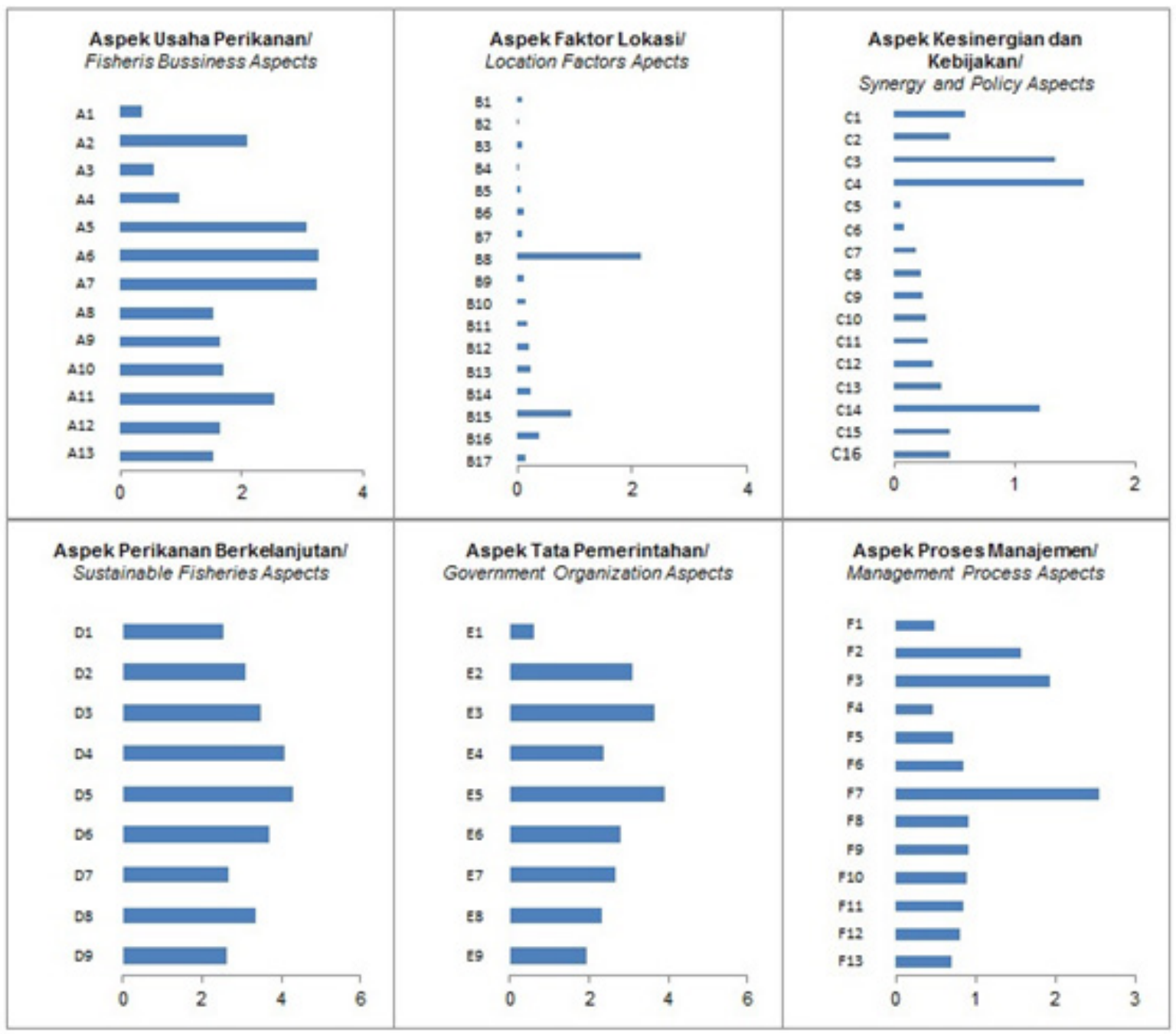

Gambar 1. Faktor Pengungkit PEP Kabupaten Indragiri Hilir. Figure 1. Leverage Factors of FED of Indragiri Hilir District. 


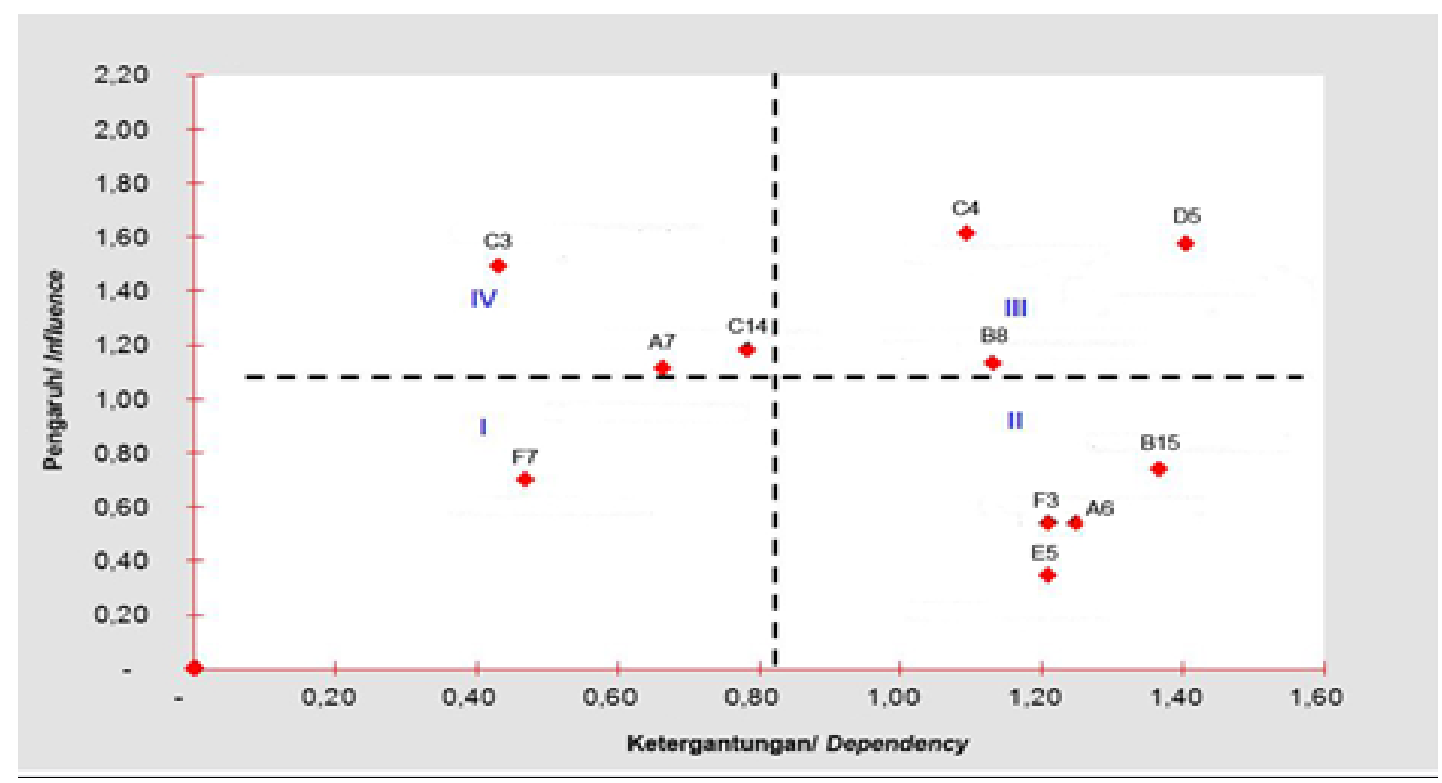

Gambar 2. Matrik Analisis Prospektif Kabupaten Indragiri Hilir. Figure 2. Matrix of Prospective Analysis of Indragiri Hilir District.

Faktor-faktor kunci yang mempengaruhi keberlanjutan pengembangan ekonomi perikanan di Kabupaten Indragiri Hilir terdiri dari faktor kunci hasil analisis prospektif MDS dan analisis kebutuhan. Hasil analisis prospektif MDS diperoleh tiga faktor kunci, sedangkan hasil analisis kebutuhan dihasilkan tiga faktor kunci (Tabel 2).

Kabupaten Indragiri Hilir berada pada sisi selatan Provinsi Riau mewakili Kabupaten Pelalawan dan Kabupaten Siak dengan perairan pantai menghadap Laut China Selatan dan potensi perikanan berupa laut dan perairan umum. Faktor kunci pertama dalam pengembangan ekonomi perikanan di daerah ini yaitu kebijakan pengembangan komunitas. Strategi pengembangan komunitas nelayan dapat mengarahkan pada perikanan yang lebih adil dan efisien serta mengurangi faktor negatif yang mengancam keberlanjutan (Nuon \& Gallardo, 2011). Faktor kunci kedua yaitu kerjasama dalam industri sejenis maupun industri hulu hilir. Kerjasama industri perikanan akan berpengaruh terhadap penggunaan sumber daya perikanan yang berkelanjutan dan ekonomis, kerjasama ini akan mengharuskan nelayan dan pengolah mengidentifikasi potensi manfaat serta kemudian mengkoordinasikan kegiatan mereka untuk memaksimalkan manfaat/keuntungan (Kodama, 2016). Faktor kunci ketiga yaitu

Tabel 2. Faktor Kunci PEP Kabupaten Indragiri Hilir.

Table 2. Key Factors of FED in Indragiri Hilir District.

\begin{tabular}{cll}
\hline No & \multicolumn{1}{c}{$\begin{array}{c}\text { Faktor Kunci dari Analisis MDS/ } \\
\text { Key Factors of MDS Analysis }\end{array}$} & $\begin{array}{c}\text { Faktor Kunci dari analisis Kebutuhan/ } \\
\text { Key Factors of Need Analysis }\end{array}$ \\
\hline 1 & $\begin{array}{l}\text { Kebijakan pengembangan komunitas/ Community } \\
\text { development policy }\end{array}$ & \\
2 & $\begin{array}{l}\text { Kerjasama dalam industri sejenis maupun industri hulu- } \\
\text { hilir/ Collaboration in similar industries and upstream- } \\
\text { downstream industries } \\
\text { Kontribusi pengembangan ekonomi perikanan terhadap } \\
\text { peningkatan kualitas hidup dan kesejahteraan masyarakat } \\
\text { lokal/ Contribution of fisheries economic development to } \\
\text { improving the quality of life and welfare of local communities }\end{array}$ & \\
4 & \multicolumn{1}{l}{ Faktor kebijakan pemerintah/ Factors of } \\
5 & & $\begin{array}{l}\text { government policy } \\
\text { Ketersediaan SDM/ HR availability } \\
\text { Sarana dan prasarana perikanan/ Fisheries } \\
\text { facilities and infrastructure }\end{array}$ \\
\hline
\end{tabular}


kontribusi pengembangan ekonomi perikanan terhadap peningkatan kualitas hidup dan kesejahteraan masyarakat lokal. Pengembangan ekonomi perikanan tetap harus memperhatikan keberpihakan kepada masyarakat lokal sehingga pemanfaatan dapat tercapai secara berkelanjutan (Adam, 2012). Faktor kunci keempat yaitu Faktor kebijakan pemerintah. Komponen model kebijakan pemerintah yang berpeluang memberikan pengaruh pada setiap level kebijakan adalah kebijakan politik, ekonomi, sosial dan budaya, Pada level pusat keberpihakan pengembangan kawasan perikanan hanya pada aspek sosial, sedangkan di level provinsi dan kabupaten pada aspek politik dan sosial (Abrahamsz, 2011). Faktor kunci kelima yaitu Ketersediaan sumber daya manusia. Pengembangan sumber daya manusia perikanan merupakan sebuah keharusan bagi tercapainya pemanfaatan sumber daya perikanan yang optimal (Khairus, 2009). Faktor kunci keenam yaitu penyediaan sarana dan prasarana perikanan. Pembangunan infrastruktur sektor perikanan laut yang tepat terbukti meningkatkan produksi dan keberlanjutan ekonomi perikanan (Viswanatha, Senthiladeban, Rajakumar \& Infantina, 2015).

\section{Faktor Kunci Pengembangan Ekonomi Perikanan Kabupaten Bengkalis}

Kabupaten Bengkalis seperti halnya Kabupaten pesisir lainnya, juga memiliki potensi yang besar dibidang perikanan tangkap. Namun, tantangan yang dihadapi daerah ini yaitu terjadinya overfishing pada beberapa komoditas pertikanan tangkap (Rengi, Tang, Syahza, Siregar, 2015). Produksi perikanan selama Tahun 2016 sekitar 7,58 ribu ton, hampir $95 \%$ berasal dari perikanan laut (BPS Kabupaten Bengkalis, 2017). Beberapa permasalahan seperti overfishing, penggunaan alat tangkap tidak ramah lingkungan dan konflik nelayan menjadi isu penting dalam pertimbangan kebijakan pengelolaan perikanan daerah ini (Rengi, Ramadona \& Ardiansyah, 2017).

Hasil analisis MDS menunjukkan bahwa dari 77 atribut yang dianalisis, diperoleh 8 faktor/ atribut sensitif yang berpengaruh terhadap keberlanjutan pengembangan ekonomi perikanan di Kabupaten Bengkalis. Faktor tersebut antara lain; upaya fasilitas pemodalan (A7); peluang kerjasama dalam industri sejenis maupun industri hulu-hilir (B8); akses ke pelabuhan udara (B15); kebijakan

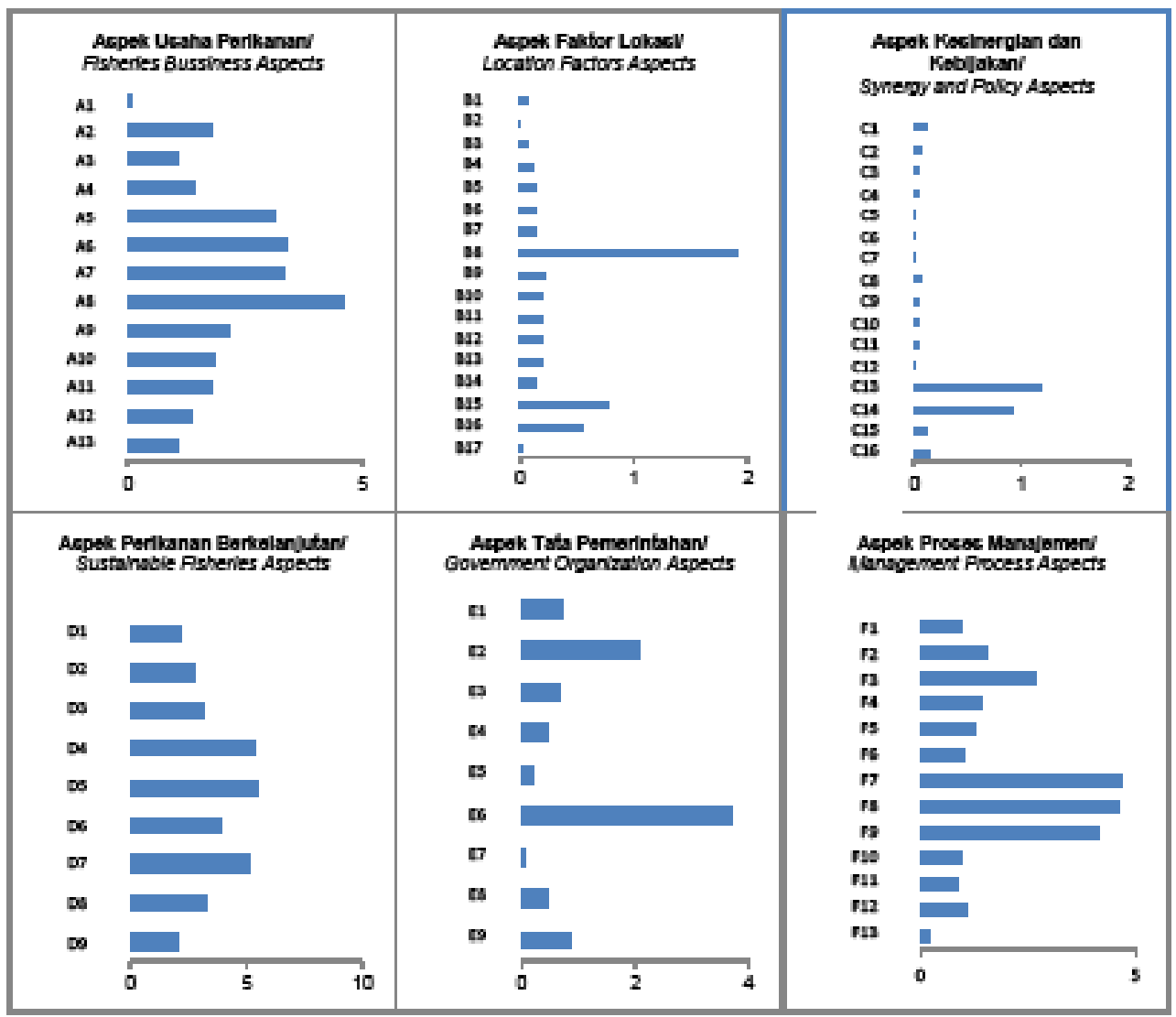

Gambar 3. Faktor Pengungkit PEP Kabupaten Bengkalis. Figure 3. Leverage Factors of FED of Bengkalis District. 
pemberdayaan UKM (C13); Kebijakan persaingan usaha (C14); kontribusi pengembangan ekonomi perikanan terhadap peningkatan kualitas hidup dan kesejahteraan masyarakat lokal (D5); restrukturisasi organisasi pemerintahan (E5); Sinkronisasi lintas sektoral dan spasial dalam perencanaan PEP (F7). Delapan faktor/ atribut sensitif yang berpengaruh terhadap keberlanjutan pengembangan ekonomi perikanan di Kabupaten Bengkalis ini selanjutnya dianalisis menggunakan analisis prospektif.

Faktor-faktor kunci yang mempengaruhi keberlanjutan pengembangan ekonomi perikanan di Kabupaten Bengkalis terdiri dari faktor kunci hasil analisis prospektif MDS dan analisis kebutuhan. Hasil analisis prospektif MDS diperoleh tiga faktor kunci, sedangkan hasil analisis kebutuhan dihasilkan dua faktor kunci (Tabel 3).

Kabupaten Bengkalis merupakan kabupaten yang berada pada sisi utara Provinsi Riau mewakili Kota Dumai, Kabupaten Rokan Hilir dan Kabupaten Kepulauan Meranti dengan perairan pantai menghadap Selat Malaka dan potensi perikanan berupa laut/perikanan tangkap. Faktor kunci pertama dalam pengembangan ekonomi perikanan di daerah ini adalah peluang

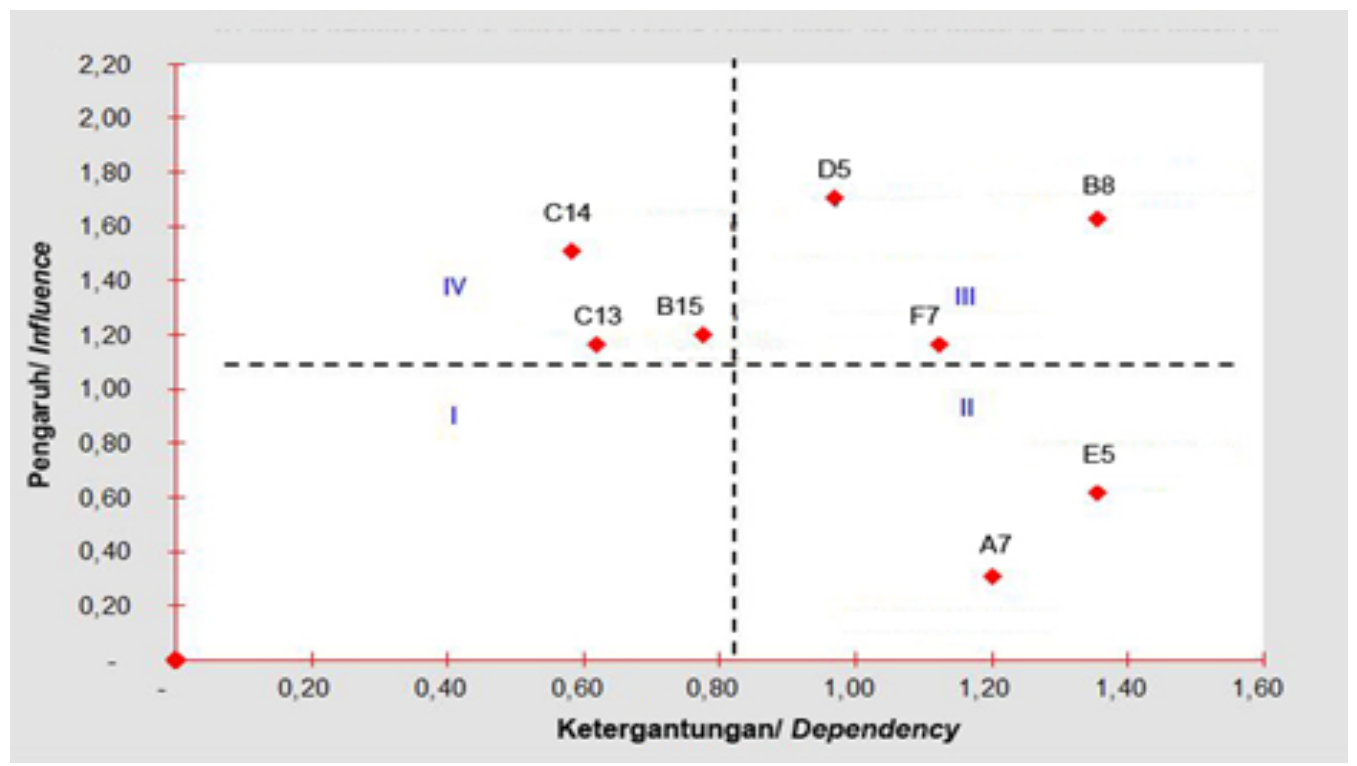

Gambar 4. Matrik Analisis Prospektif Kabupaten Bengkalis. Figure 4. Matrix of Prospective Analysis of Bengkalis District.

Tabel 3. Faktor Kunci PEP Kabupaten Bengkalis.

Table 3. Key Factors of FED in Bengkalis District.

\begin{tabular}{|c|c|c|}
\hline No & $\begin{array}{l}\text { Faktor Kunci dari Analisis MDS/ } \\
\text { Key Factors of MDS Analysis }\end{array}$ & $\begin{array}{l}\text { Faktor Kunci Dari Analisis Kebutuhan/ } \\
\text { Key Factors of Need analysis }\end{array}$ \\
\hline 1 & $\begin{array}{l}\text { Peluang kerjasama dalam industri sejenis maupun } \\
\text { industri hulu-hilir/ Cooperation opportunities in similar } \\
\text { industries and upstream-downstream industries }\end{array}$ & \\
\hline 2 & $\begin{array}{l}\text { Kontribusi pengembangan ekonomi perikanan } \\
\text { terhadap peningkatan kualitas hidup dan kesejahteraan } \\
\text { masyarakat lokal/ Contribution of fisheries economic } \\
\text { development to improving the quality of life and welfare } \\
\text { of local communities }\end{array}$ & \\
\hline 3 & $\begin{array}{l}\text { Sinkronisasi lintas sektoral dan spasial dalam } \\
\text { perencanaan PEPI Cross-sectoral and spatial } \\
\text { synchronization in FED planning }\end{array}$ & \\
\hline 4 & & $\begin{array}{l}\text { Faktor kebijakan pemerintah/ Factors of } \\
\text { government policy }\end{array}$ \\
\hline 5 & & Ketersediaan SDM/ HR availability \\
\hline
\end{tabular}


kerjasama dalam industri sejenis maupun industri hulu-hilir. Faktor kunci kedua yaitu kontribusi pengembangan ekonomi perikanan terhadap peningkatan kualitas hidup dan kesejahteraan masyarakat lokal. Faktor kunci ketiga yaitu sinkronisasi lintas sektoral dan spasial dalam perencanaan PEP. Dukungan lintas sektoral merupakan salah satu kunci dalam pengembangan perikanan (Zulkarnain, Purwanti \& Indrayani, 2013). Faktor kunci keempat yaitu faktor kebijakan pemerintah. Faktor kunci kelima yaitu ketersediaan sumber daya manusia.

\section{Faktor Kunci Pengembangan Ekonomi Perikanan Kabupaten Kampar}

Potensi pengembangan usaha perikanan di Kabupaten Kampar cukup luas dan mempunyai peluang yang cukup besar untuk dikembangkan. Kabupaten Kampar merupakan penyumbang terbesar produksi ikan budi daya air tawar di Provinsi Riau. Data Badan Pusat Statistik (BPS Kabupaten Kampar, 2016) menyebutkan bahwa tahun 2015, sekitar 66,97 persen produksi perikanan budi daya Provinsi Riau atau sebanyak
57.868,63 ton disumbangkan Kabupaten Kampar. Kabupaten Kampar telah ditetapkan sebagai Kawasan sentra Produksi Perikanan Air Tawar di Propinsi Riau melalui surat keputusan Gubernur Riau Nomor: KPTS. 999/II/2000. Selain usaha budi daya perikanan, usaha pengolahanpun telah dilaksanakan masyarakat baik perorangan maupun melalui UMKM, tetapi usaha ini masih tradisional dan baru sebatas mempertahankan mutu ikan yang tidak terjual (KKP, 2018).

Faktor pengungkit hasil analisis MDS diperoleh 8 atribut yang sensitif berpengaruh terhadap keberlanjutan pengembangan ekonomi perikanan di Kabupaten Kampar yaitu; pusat layanan investasi (A8); fasilitas pelatihan kewirausahaan (A4); jumlah lembaga keuangan lokal (B9); kebijakan pengembangan keahlian (C9); kebijakan pemberdayaan UKM (C13); kontribusi PEP terhadap peningkatan kualitas hidup dan kesejahteraan masyarakat (D5); status asosiasi industri komoditi/ forum bisnis (E3); sinkronisasi lintas sektoral dan spasial dalam perencanaan PEP (F7). Faktor ini selanjutnya dianalisis secara prospektif (Gambar 6).

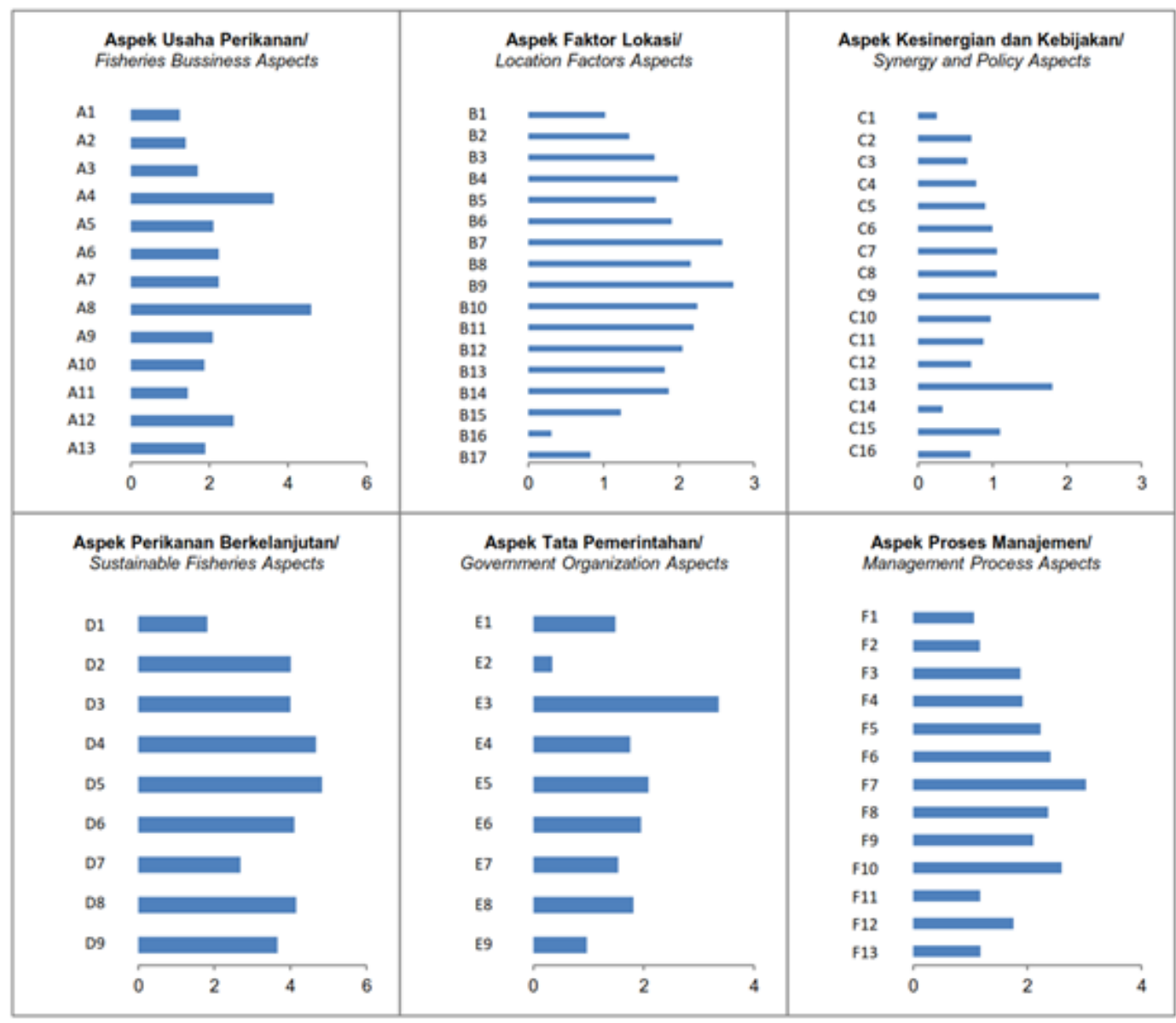

Gambar 5. Faktor Pengungkit PEP Kabupaten Kampar. Figure 5. Leverage Factor of PEP of Kampar Regency. 


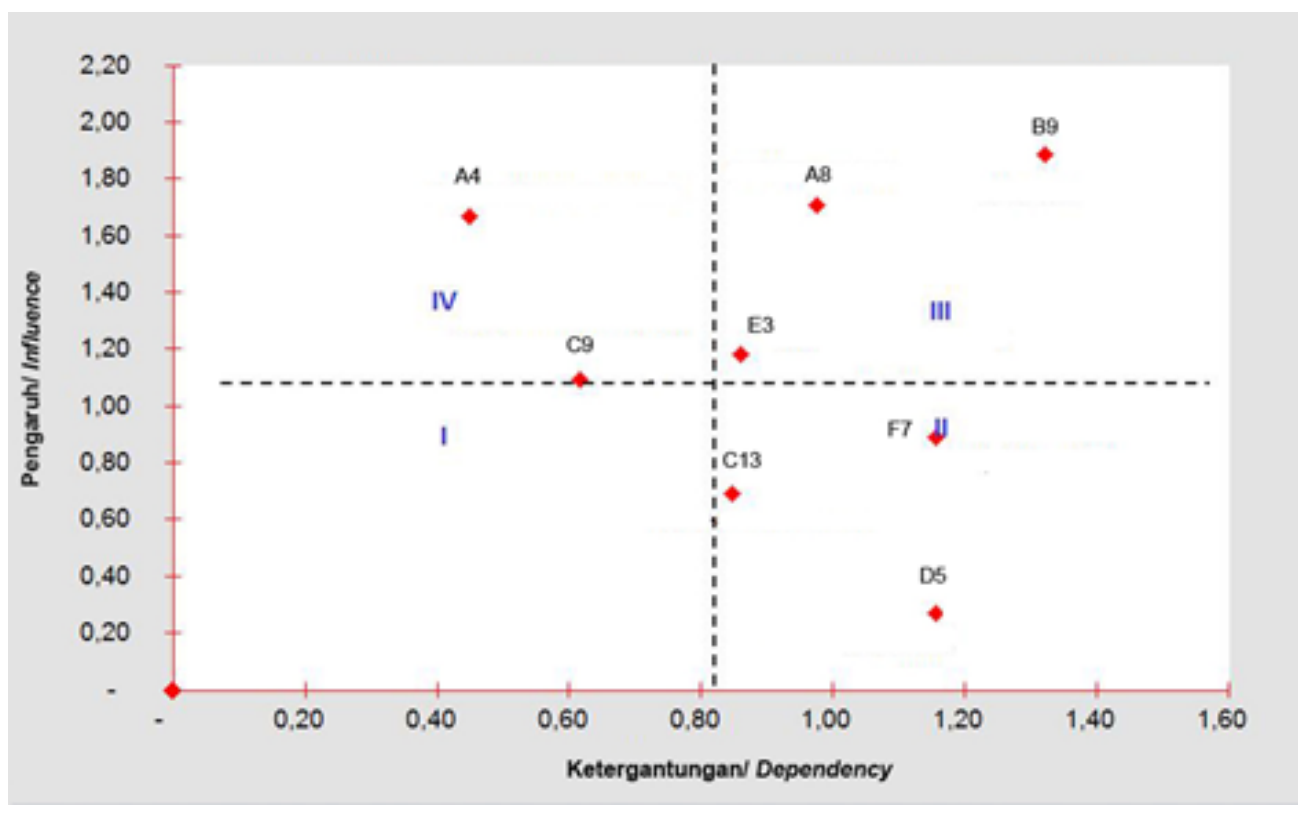

Gambar 6. Matrik Analisis Prospektif Kabupaten Kampar
Capture 6. Matrix of Prospective Analysis of Kampar Regency

Faktor-faktor kunci yang mempengaruhi keberlanjutan pengembangan ekonomi perikanan di Kabupaten Kampar terdiri dari faktor kunci hasil analisis prospektif MDS dan analisis kebutuhan. Hasil analisis prospektif MDS diperoleh tiga faktor kunci, sementara analisis kebutuhan diperoleh dua faktor kunci. Selanjutnya faktorfaktor yang sama dari kedua hasil analisis tersebut digabung dan dihitung satu faktor yang disajikan pada Tabel 4.

Kabupaten Kampar mewakili daerah sisi barat Provinsi Riau memiliki potensi perikanan darat sebagai daerah penghasil budi daya air tawar seperti Kuansing, Pekanbaru, Rokan Hulu dan Indragiri Hulu. Dari hasil analisis gabungan (Tabel 3) menunjukkan bahwa ditemukan 5 (lima) atribut sebagai faktor kunci pengembangan ekonomi perikanan Kabupaten Kampar.
Faktor kunci pertama yaitu pusat layanan investasi. Pusat layanan investasi berfungsi dalam menciptakan iklim yang kondusif untuk pengembangan usaha dan penciptaan lapangan kerja, serta mengembangkan pemberdayaan masyarakat dan kemitraan dalam proses pembangunan (Suparno, 2017). Faktor kunci kedua yaitu jumlah lembaga keuangan lokal. Peran lembaga keuangan melalui penyuluh memberikan dampak yang signifikan bagi pengembangan perikanan (Nazir, Chauhan, Khati \& Arya, 2018.). Faktor kunci ketiga yaitu status asosiasi industri komoditi/ forum bisnis. Optimalisasi peran dan fungsi asosiasi industri/komoditi/forum bisnis memiliki pengaruh didalam perbaikan kebijakan pemerintah di bidang pengembangan ekonomi lokal (Kunto, 2012). Faktor kunci keempat yaitu ketersediaan SDM. Faktor kunci kelima yaitu sarana dan prasarana perikanan.

Tabel 4. Faktor Kunci PEP Kabupaten Kampar. Table 4. Key Factors of PEP in Kampar Regency.

\begin{tabular}{cll}
\hline No & \multicolumn{1}{c}{$\begin{array}{c}\text { Faktor Kunci dari Analisis MDS/ } \\
\text { Key Factors of MDS Analysis }\end{array}$} & $\begin{array}{c}\text { Faktor Kunci dari analisis Kebutuhan/ } \\
\text { Key Factors of Need analysis }\end{array}$ \\
\hline 1 & $\begin{array}{l}\text { Pusat layanan investasi/ Investment service center } \\
\text { Jumlah lembaga keuangan lokal/ } \\
\text { Number of local financial institutions }\end{array}$ & \\
3 & $\begin{array}{l}\text { Status asosiasi industri komoditi (forum bisnis)/ Status } \\
\text { of commodity industry associations (business forums) }\end{array}$ & $\begin{array}{l}\text { Ketersediaan SDM/ HR availability } \\
\text { Sarana dan prasarana perikanan/ Fisheries } \\
\text { facilities and infrastructure }\end{array}$ \\
\hline
\end{tabular}




\section{KESIMPULAN DAN REKOMENDASI KEBIJAKAN}

\section{Kesimpulan}

Kabupaten Indragiri Hilir dengan perairan pantai menghadap Laut China Selatan dan potensi perikanan berupa laut dan perairan umum memiliki faktor kunci PEP sebagai berikut: (1) kebijakan pengembangan komunitas; (2) kerjasama dalam industri sejenis maupun industri hulu-hilir; (3) kontribusi pengembangan ekonomi perikanan terhadap peningkatan kualitas hidup dan kesejahteraan masyarakat lokal; (4) faktor kebijakan pemerintah; (5) Ketersediaan SDM, dan; (6) sarana dan prasarana perikanan.

Kabupaten Bengkalis dengan perairan pantai menghadap Selat Malaka dan potensi perikanan berupa laut/perikanan tangkap memiliki faktor kunci PEP sebagai berikut: (1) peluang kerjasama dalam industri sejenis maupun industri hulu-hilir; (2) kontribusi pengembangan ekonomi perikanan terhadap peningkatan kualitas hidup dan kesejahteraan masyarakat lokal; (3) sinkronisasi lintas sektoral dan spasial dalam perencanaan PEP; (4) faktor kebijakan pemerintah, dan; (5) ketersediaan SDM.

Kabupaten Kampar mewakili perikanan darat sebagai daerah penghasil budi daya air tawar memiliki faktor kunci PEP sebagai berikut; (1) pusat layanan investasi, (2) jumlah lembaga keuangan lokal, (3) status asosiasi industri komoditi/ forum bisnis, (4) ketersediaan SDM, (5) sarana dan prasarana perikanan.

\section{Rekomendasi Kebijakan}

Penyusunan kebijakan pengembangan ekonomi perikanan di Provinsi Riau khususnya pada lokasi kajian dilakukan dengan melihat interaksi antara komponen-komponen keberlanjutan. Permasalahan pengembangan ekonomi perikanan bersifat kompleks dengan banyak faktor (atribut) yang mempengaruhi keberlanjutannya. Untuk itu dilakukan pembatasan pada atribut/ faktor kunci (dominan) yang mempengaruhi keberlanjutan pengembangan ekonomi perikanan pada masing-masing daerah. Strategi dibangun berdasarkan pendekatan integratif terhadap seluruh atribut kunci yang berpengaruh terhadap pengembangan ekonomi perikanan. Selain itu diperlukan kerjasama seluruh stakeholder terkait. Faktor kunci PEP yang telah ditemukan pada setiap wilayah dapat menjadi acuan dalam menyusun rencana strategis dan rencana tindak yang lebih implementatif serta rekomendasi program kerja dan strategi (Kunto, 2012., Rengi dan Ramadona, 2018).

\section{Rekomendasi bagi Pemerintah Daerah Kabupaten Indragiri Hilir}

1. Penguatan kelembagaan kelompok nelayan dan kearifan lokal

2. Peningkatan prasarana perikanan (PPI/TPI)

3. Sinkronisasi dan optimalisasi peran stakeholders dalam PEP

4. Membentuk Pokmaswas (Kelompok Masyarakat Pengawas Perikanan) sebagai lembaga lokal yang berfungsi membantu pemerintah dalam tata kelola usaha perikanan.

5. Pembangunan dan pengembangan kawasan penyangga.

6. Peningkatan kualitas SDM perikanan (nelayan dan tenaga kerja UMKM Perikanan)

\section{Rekomendasi bagi Pemerintah Daerah Kabupaten} Bengkalis

1. Penguatan Forum Stakeholder Perikanan

2. Upaya pemetaan potensi ekonomi lokal non perikanan sebagai mata pencarian alternatif

3. Meningkatkan fungsi Pokmaswas (Kelompok Masyarakat Pengawas Perikanan)

4. Optimalisasi pengembangan keahlian (kompetensi/ketrampilan) bagi nelayan, pembudi daya dan UMKM perikanan.

5. Penguatan kelembagaan kelompok nelayan dan kearifan lokal

6. Peningkatan dan pemeliharaan prasarana perikanan (PPI/TPI) seperti infrastruktur energi, komunikasi dan transportasi.

\section{Rekomendasi Bagi Pemerintah daerah Kabupaten Kampar}

1. Promosi usaha dan informasi bisnis melalui berbagai media terutama produk unggulan perikanan berupa ikan patin.

2. Peningkatan pangsa pasar produk UMKM Kabupaten Kampar secara periodik dan berkesinambungan.

3. Kemudahan perijinan dan peraturan tentang kemudahan investasi

4. Peningkatan dan kemudahan akses lembaga keuangan mikro perikanan.

5. Optimalisasi pengembangan jaringan usaha antar pelaku ekonomi, antar sentra UMKM 
melalui sistem terintegrasi antar sentra/klaster UMKM dengan fasilitasi dan pendampingan dari stakeholders terkait

6. Penerapan GMP dan SSOP dalam proses pengolahan ikan

7. Pembangunan sarana penunjang seperti Unit Pengolahan limbah / IPAL.

\section{UCAPAN TERIMA KASIH}

Ucapan terima kasih disampaikan kepada Badan Penelitian dan Pengembangan (BPP) Provinsi Riau dalam pelaksanaan penelitian ini, para Reviewer, serta pihak-pihak yang telah membantu hingga selesainya penyusunan karya ilmiah ini.

\section{DAFTAR PUSTAKA}

Abrahamsz, J. (2011). Analisis Pengaruh Kebijakan Pemerintah terhadap Pengembangan Kawasan Perikanan Di Kabupaten Maluku Tengah. Jurnal Triton, Vol. 7 (1), 1 - 12. Diterima dari https://ejournal.unpatti.ac.id/ppr_paperinfo_Ink. php?id=1151

Adam, L. (2012). Kebijakan Pengembangan Perikanan Berkelanjutan (Studi Kasus: Kabupaten Wakatobi, Provinsi Sulawesi Tenggara dan Kabupaten Pulau Morotai, Provinsi Maluku Utara). Jurnal Perikanan dan Kelautan, Vol. II No. 2 : 115-126. DOI: http://dx.doi.org/10.33512/jpk.v2i2.28

Adiga, M.S., P.S. Ananthan, V. Ramasubramanian, H.V.D. Kumari. (2015). Validating RAPFISH Sustainability Indicators: Focus on Multi-Disciplinary Aspects of Indian Marine Fisheries. Marine Policy, Vol. 60 (2015) 202-207. doi: http:// dx.doi.org/10.1016/j.marpol.2015.06.032.

Bappenas. (2007.) Manual Penentuan Status dan Pengungkit PEL. Direktorat Perekonomian Daerah. Badan Perencanaan Pembangunan Nasional. Jakarta.

[BPS] Badan Pusat Statistik Provinsi Riau. (2017). Riau dalam Angka. Pekanbaru.

[BPS] Badan Pusat Statistik Kabupaten Bengkalis. (2017). Bengkalis dalam Angka. Bengkalis.

[BPS] Badan Pusat Statistik Kabupaten Kampar. (2016). Kampar dalam Angka. Bangkinang.

[FAO] Food and Agriculture Organization of the United Nation. (2007). Models for fish stock assessment. Training Center on the Methods for Fish Stock Assessment. Brest, France.

Kavanagh, P. (2001). Rapid Appraisal Of Fisheries (Rapfish) Project: Rapfish software Description (For Mic Excel). University of British Colombia, CO: Fisheries Centre. Vancouver.
Khairus, Y. (2009). Pengembangan SumberDaya Manusia Kelautan dan Perikanan Berbasis Sumber Daya Alam dan Pengaruhnya bagi Ketahanan Nasional Indonesia. [Tesis]. Yogyakarta. Program Pascasarjana Universitas Gajah Mada.

[KKP] Kementerian Kelautan dan Perikanan. 2018. Profil Potensi Usaha dan Peluang Investasi Kelautan dan Perikanan Provinsi Riau. Ditjen PDSPKP. Jakarta.

Kodama, T. (2016). Cooperative initiatives Between The Fishing and Fish-Processing Industries and The Conditions Associated With Their Implementation: Comparison Of Red Snow Crab Production Areas in Japan. Journal of National Fisheries University, Vol. 64 $\square 4 \square 293 \square 301$. Retrieved from http://www. fish-u.ac.jp/kenkyu/sangakukou/kenkyuhoukoku/ kenkyuhoukoku.html

Kunto, A. (2012). Analisis Pemetaan Status Pengembangan Ekonomi Lokal (PEL) di Kabupaten Sukoharjo. Jurnal SEPA : Vol. 9(1), 50 - 63. Diterima dari https://jurnal.uns.ac.id/ sepa/issue/archive

Nazir, I., R.S. Chauhan, A. Khati \& P. Arya. (2018). Role of Credit for The Upliftment of The Fisheries Sector. International Journal of Fisheries and Aquatic Studies; 6(2), 01-04. Retrieved from http://www.fisheriesjournal.com/archives/?year $=2018 \&$ vol $=6 \&$ issue $=2 \&$ part $=A \& A r$ ticleld $=1480$

Nuon, V. \& W. Gallardo. (2011). Perceptions of the local community on the outcome of community fishery management in Krala Peah village, Cambodia. International Journal of Sustainable Development \& World Ecology. Vol. 18, 453-460. DOI:10.1080 /13504509.2011.584199

Pitcher, T. J. (1999). Rapfish, A Rapid Appraisal Technique For Fisheries, And Its Application To The Code Of Conduct For Responsible Fisheries. FAO Fisheries Circular No. 947. University of British Colombia, CO: Fisheries Centre. Vancouver.

Ramadona, T., P. Rengi, \& Marnis. (2015). Model Pengelolaan Sumber daya Ikan Karang Berkelanjutan Di Raja Ampat. Prosiding Simposium Nasional Perikanan Karang Berkelanjutan Indonesia. Hal. 335-348.

Rengi, P. (2015). Disain Pengelolaan Lingkungan Perikanan Di Kawasan Perairan Tangkap Lebih (Overfishing) Kabupaten Bengkalis Provinsi Riau [Disertasi]. Pekanbaru. Program Pascasarjana. Universitas Riau. 248 hal.

Rengi, P., U. M. Tang, A. Syahza., Y. I. Siregar. (2015). Status, Exploration Potential and Resource Management of Kurau (Eleutheronema tetradactylum) Fish in Overfishing Area (Case Study in Bengkalis District, Riau Province). International Journal of Research In Earth \& Environmental Sciences. Vol. 3 (02), 08-13. Retrieved from http://www.ijsk.org/ijrees.html. 
Rengi, P., T. Ramadona. \& Ardiansyah. (2017). Fishing Resource Management Policies Of Bengkalis District Riau Province. International Journal Of Social Sciences, 51(1):42-50. Retrieved from http://tijoss.com/51volume.html

Rengi, P. \& T. Ramadona. (2018). Model Pengembangan Ekonomi Wilayah dan Kelembagaan Usaha Perikanan Kabupaten Kepulauan Meranti. Jurnal TECHNO-FISH Vol. 2 (2), 79-91. DOI: 10.25139/ tf.v2i2.984.

Rosyidah, L., \& M. D. Erlina. (2018). Fishery Business Development Strategy in Indragiri Hilir District, Riau Province. ECSOFiM: Journal of Economic and Social of Fisheries and Marine. Vol. 05(02): 116 - 128. DOI: ub.ecsofim.2018.005.02.01.

Suparno. (2017). Inovasi Daerah untuk Meningkatkan Iklim Investasi. Jurnal Mimbar Administrasi, Vol. 1(1), 1-14. Dierima dari http://jurnal.untagsmg. ac.id/index.php/mia/article/view/567

Triyono \& T. Ramadona. Penentuan Produk Unggulan Perikanan dan Pengembangannya di Pulau Terdepan Indonesia (Kasus di Kabupaten Natuna). Jurnal TECHNO-FISH Vol. 2 (2), 100-112. DOI: 10.25139/tf.v2i2.101.

Viswanatha, B.S., Senthiladeban R., Rajakumar M. \& Infantina, J.A. (2015). An Overview of Marine Fisheries Infrastructure and Fish Utilization Pattern in Karnataka, India. International Journal of Fisheries and Aquatic Studies; 2(4), 233-238. Retrieved from http://www.fisheriesjournal.com/ vol2issue4/2-4-64.1.html

Zulkarnain, M., P. Purwanti, \& E. Indrayani. (2013). Analisis Pengaruh Nilai Produksi Perikanan Budi daya Terhadap Produk Domestik Bruto Sektor Perikanan di Indonesia. Jurnal ECSOFiM, Vol. 1(1), 52-68. Diterima dari https://ecsofim.ub.ac. id/index.php/ecsofim/article/view/13. 
Lampiran 1. Dimensi dan Atribut Pengembangan Ekonomi Perikanan. Appendix 1. Dimensions and Attributes of Fisheries Economic Development.

\begin{tabular}{|c|c|c|}
\hline $\begin{array}{l}\text { Dimensi/ } \\
\text { Dimensions }\end{array}$ & $\begin{array}{l}\text { Kodel } \\
\text { Code }\end{array}$ & Indikator (Atribut)/ Indicator (Attribute) \\
\hline $\begin{array}{l}\text { Aspek Usaha } \\
\text { Perikanan/ Fisheries }\end{array}$ & & $\begin{array}{l}\text { Peraturan tentang kemudahan investasi perikanan/ Regulations concerning the } \\
\text { ease of fisheries investment }\end{array}$ \\
\hline \multirow[t]{12}{*}{ Business Aspects } & A1 & \\
\hline & A2 & Informasi prospek bisnis perikanan/ Information on fisheries business prospects \\
\hline & A3 & Kepastian berusaha dan kepastian hukum/ Business certainty and legal certainty \\
\hline & A4 & Faktor keamanan/ Safety factor \\
\hline & A5 & $\begin{array}{l}\text { Kampanye peluang usaha perikanan/ Fisheries business opportunity campaign } \\
\text { Pusat pelayanan investasi dengan Jasa layanan konsultasi investasi perikanan/ } \\
\text { Investment service center with fisheries investment consulting services }\end{array}$ \\
\hline & A7 & $\begin{array}{l}\text { Upaya Fasilitasi permodalan bagi dunia usaha perikanan oleh Pemda/ Efforts } \\
\text { to facilitate capital for the world of fisheries business by the Regional Government }\end{array}$ \\
\hline & A8 & $\begin{array}{l}\text { Promosi produk perikanan untuk memperluas pasar oleh pemda/ Promotion of } \\
\text { fishery products to expand the market by the local government }\end{array}$ \\
\hline & A9 & $\begin{array}{l}\text { Upaya Pemda untuk peningkatan teknologi, manajemen, dan kelembagaan } \\
\text { usaha perikanan lokal / The efforts of the Regional Government to improve } \\
\text { technology, management and institutions of local fisheries }\end{array}$ \\
\hline & A10 & $\begin{array}{l}\text { Fasilitasi Pelatihan kewirausahaan bagi masyarakat perikanan/ Facilitation of } \\
\text { entrepreneurship training for fishing communities }\end{array}$ \\
\hline & A11 & $\begin{array}{l}\text { Pendampingan dan monitoring bisnis pelaku usaha baru perikanan/ Mentoring } \\
\text { and monitoring the business of new fisheries business actors }\end{array}$ \\
\hline & A12 & $\begin{array}{l}\text { Insentif pemda dalam bentuk pemberian dana stimulan, dan keringanan biaya } \\
\text { perijinan/ Regional government incentives in the form of stimulant funding, and } \\
\text { licensing fee relief }\end{array}$ \\
\hline & A13 & $\begin{array}{l}\text { Kecepatan pengurusan ijin bagi investasi baru/ Speed of processing permits for } \\
\text { new investments }\end{array}$ \\
\hline \multirow{17}{*}{$\begin{array}{l}\text { Aspek Faktor Lokasi/ } \\
\text { Factor Location } \\
\text { Aspects }\end{array}$} & B1 & Aksesibilitas dari dan ke lokasi / Accessibility from and to location \\
\hline & B2 & Akses ke pelabuhan laut/ Access to the sea port \\
\hline & B3 & Akses ke pelabuhan udara/ Access to the airport \\
\hline & B4 & Sarana transportasi/ Transportation facilities \\
\hline & B5 & Infrastruktur komunikasi/ Communication infrastructure \\
\hline & B6 & Infrastruktur energi/ Energy infrastructure \\
\hline & B7 & Ketersediaan air bersih/ Availability of clean water \\
\hline & B8 & Tenaga kerja terampil/ Skilled workforce \\
\hline & B9 & Jumlah Lembaga keuangan lokal / Number of local financial institutions \\
\hline & B10 & $\begin{array}{l}\text { Peluang kerjasama dalam industri sejenis maupun industri hulu-hilir/ Cooperation } \\
\text { opportunities in similar industries and upstream-downstream industries }\end{array}$ \\
\hline & B11 & Lembaga penelitian/ Research institutions \\
\hline & B12 & Kualitas permukiman/ Quality of settlements \\
\hline & B13 & Kualitas lingkungan/ Environmental quality \\
\hline & B14 & Kualitas dari fasilitas pendidikan/ Quality of educational facilities \\
\hline & B15 & Kualitas pelayanan kesehatan/ Quality of health services \\
\hline & B16 & Fasilitas umum dan fasilitas Sosial/ Public facilities and Social facilities \\
\hline & B17 & Etos kerja SDM/ HR work ethic \\
\hline \multirow{5}{*}{$\begin{array}{l}\text { Aspek Kesinergian } \\
\text { dan Kebijakan/ } \\
\text { Synergy and Policy } \\
\text { Aspects }\end{array}$} & $\mathrm{C} 1$ & Kebijakan peningkatan investasi/ Policy for increasing investment \\
\hline & $\mathrm{C} 2$ & Kebijakan promosi daerah/ Regional promotion policy \\
\hline & C3 & Kebijakan persaingan usaha / Business competition policy \\
\hline & C4 & $\begin{array}{l}\text { Kebijakan pemberdayaan UKM Perikanan / Policy for empowering Fisheries } \\
\text { SMEs }\end{array}$ \\
\hline & C5 & $\begin{array}{l}\text { Kebijakan peningkatan peran Perusahaan Daerah/ Policy to increase the role of } \\
\text { Regional Companies }\end{array}$ \\
\hline
\end{tabular}


Lanjutan Lampiran 1/Continue Appendix 1

\begin{tabular}{|c|c|c|}
\hline $\begin{array}{c}\text { Dimensi/ } \\
\text { Dimensions }\end{array}$ & $\begin{array}{l}\text { Kodel } \\
\text { Code }\end{array}$ & Indikator (Atribut)/ Indicator (Attribute) \\
\hline & C6 & $\begin{array}{l}\text { Kebijakan pengembangan jaringan usaha antar pelaku ekonomi/ Policy for } \\
\text { developing business networks among economic actors }\end{array}$ \\
\hline & $\mathrm{C} 7$ & Kebijakan informasi bursa tenaga kerja/ Labor market information policy \\
\hline & $\mathrm{C} 8$ & $\begin{array}{l}\text { Kebijakan Pengembangan keahlian (peningkatan keterampilan)/ Skill development } \\
\text { program (skills improvement) }\end{array}$ \\
\hline & C9 & Kebijakan pemberdayaan masyarakat berbasis kemitraan dengan dunia usaha \\
\hline & $\mathrm{C} 10$ & $\begin{array}{l}\text { Kebijakan pengurangan kemiskinan secara partisipatif/ Participatory poverty } \\
\text { reduction policies }\end{array}$ \\
\hline & C11 & $\begin{array}{l}\text { Kebijakan pembangunan kawasan industri hinterland/ industri/ Development } \\
\text { policy for hinterland / industry industries }\end{array}$ \\
\hline & $\mathrm{C} 12$ & $\begin{array}{l}\text { Kebijakan pengembangan pusat pertumbuhan di perdesaan / Policy for } \\
\text { developing centers of growth in rural areas }\end{array}$ \\
\hline & $\mathrm{C} 13$ & Kebijakan pengembangan komunitas / Community development policy \\
\hline & C14 & $\begin{array}{l}\text { Kebijakan kerjasama antar daerah (pemda)/ Cooperation policy between regions } \\
\text { / regional governments }\end{array}$ \\
\hline & C15 & $\begin{array}{l}\text { Kebijakan tata ruang PEP (Pengembangan Ekonomi Perikanan)/ PEP spatial } \\
\text { planning policy }\end{array}$ \\
\hline & C16 & $\begin{array}{l}\text { Kebijakan pengembangan jaringan usaha antar sentra usaha/ Policy for } \\
\text { developing business networks between business centers }\end{array}$ \\
\hline
\end{tabular}

\begin{tabular}{l}
\hline Aspek Perikanan \\
Berkelanjutan/ \\
Sustainable Fisheries \\
Aspects
\end{tabular}

D1 Sistem industri yang Berkelanjutan / Sustainable industrial systems

\section{Aspects}

D2 Pengembangan industri pendukung untuk keberlanjutan sistem industri/ Development of supporting industries for industrial system sustainability

D3 Jumlah perusahaan yang telah memiliki Business plan/ Number of companies that have a business plan

D4 Jumlah perusahaan yang melakukan Inovasi pengembangan produk dan pasar/ Number of companies that carry out product development and market innovations

D5 Kontribusi PEP terhadap peningkatan kualitas hidup dan kesejahteraan masyarakat lokal/ PEP's contribution to improving the quality of life and welfare of local communities

PEP mempertimbangkan Keberadaan adat dan kelembagaan lokal/ PEP

D6 considers the existence of adat and local institutions

Kebijakan pemecahan permasalahan lingkungan / Environmental problem

D7 solving policies

Pemanfaatan sumberdaya perikanan ramah lingkungan/ Use of environmentally

D8 friendly fisheries resources

Kebijakan konservasi sumberdaya perikanan / Fisheries resource conservation

D9 policy

Aspek Tata

Pemerintahan/

Governance Aspects

E1 Kemitraan di bidang infrastruktur / Partnership in infrastructure

E2 Kemitraan di bidang promosi dan perdagangan/ Partnership in the field of promotion and trade

E3 Kemitraan di bidang pembiayaan usaha (a.l.: penjaminan, penyaluran kredit, PKBL)/ Partnership in the field of business financing

E4 Reformasi sistem insentif pengembangan SDM aparatur/ Reforming the incentive system for apparatus HR development

E5 Restrukturisasi organisasi Pemerintah/ Restructuring Government organizations

E6 Prosedur pelayanan administrasi publik/ Procedure for public administration services

E7 Status Asosiasi industri/komoditi/ Forum Bisnis/ Status of industry / commodity associations / business forums

E8 Peran Asosiasi terhadap perbaikan kebijakan pemerintah di bidang PEP/ The role of the Association in improving government policy in the PEP field 
Lanjutan Lampiran 1/Continue Appendix 1

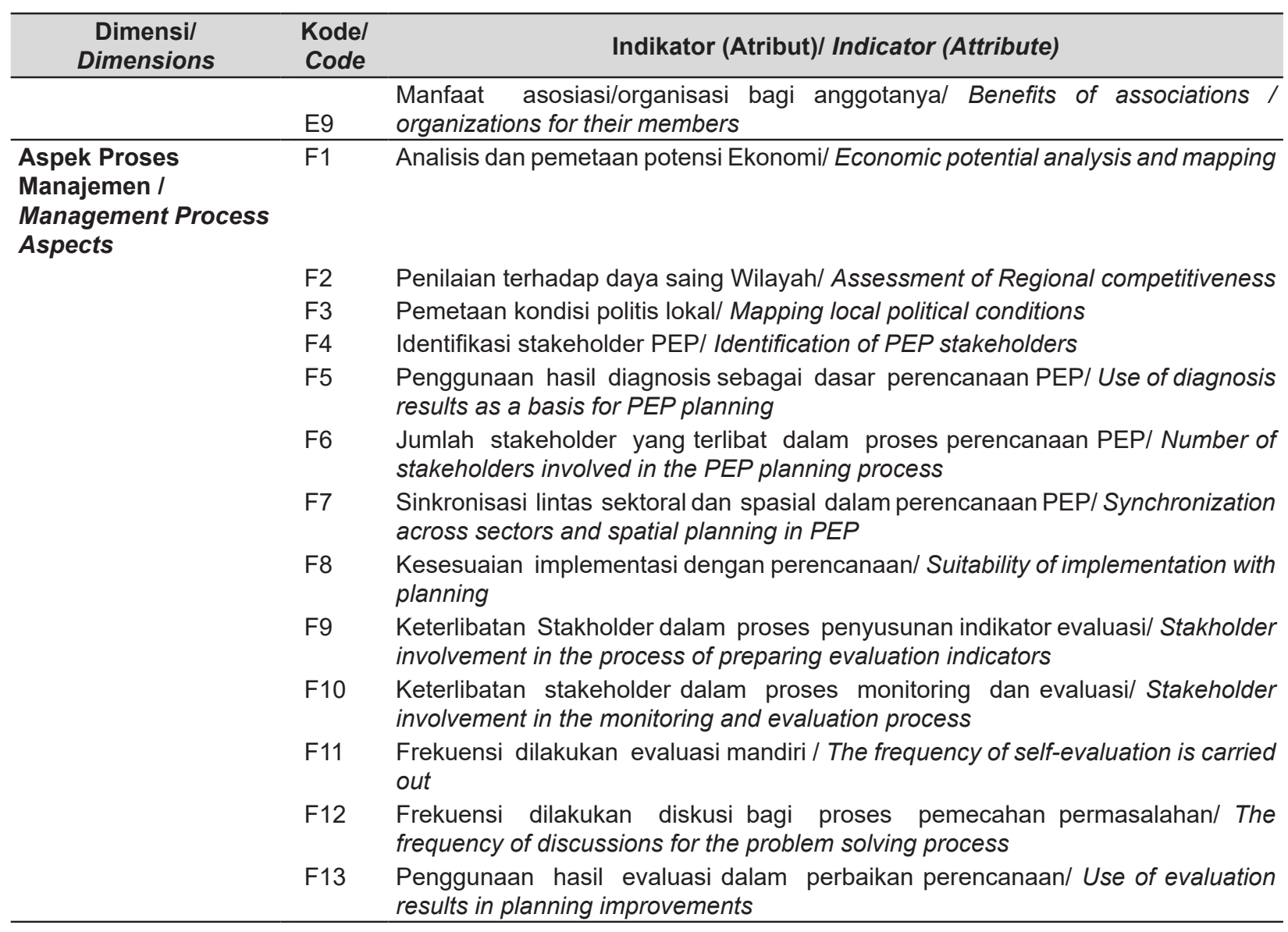

